\title{
The prostaglandin $E_{2}$ receptor PTGER2 and prostaglandin $F_{2 \alpha}$ receptor PTGFR mediate oviductal glycoprotein 1 expression in bovine oviductal epithelial cells
}

\author{
Nan $\mathrm{ZHANG}^{1)^{*}, \text { Wei MAO}}{ }^{1)^{*}}$, Ying $\mathrm{ZHANG}^{1)^{*}}$, Na HUANG ${ }^{1)}$, Bo LIU ${ }^{1)}$, Long GAO ${ }^{1)}$, \\ Shuangyi $\mathrm{ZHANG}^{1)}$ and Jinshan $\mathrm{CAO}^{\mathbf{1}}$ \\ ${ }^{1)}$ Key Laboratory of Clinical Diagnosis and Treatment Techniques for Animal Disease, Ministry of Agriculture, Laboratory of \\ Veterinary Pharmacology, College of Veterinary Medicine, Inner Mongolia Agricultural University, 010018, Hohhot, China
}

\begin{abstract}
Oviductal glycoprotein 1 (OVGP1), an oviductin, is involved in the maintenance of sperm viability and motility and contributes to sperm capacitation in the oviduct. In this study, the regulatory effects exerted by prostaglandin $\mathrm{E}_{2}\left(\mathrm{PGE}_{2}\right)$ and $\mathrm{F}_{2 \alpha}\left(\mathrm{PGF}_{2 \alpha}\right)$ on OVGP1 expression via their corresponding receptors in bovine oviductal epithelial cells (BOECs) were investigated. BOECs were cultured in vitro, and their expression of receptors of PGE $_{2}$ (PTGER1, PTGER2, PTGER3, and PTGER4) and PGF $_{2 \alpha}$ (PTGFR) was measured using RT-qPCR. $\mathrm{Ca}^{2+}$ concentration was determined with a fluorescence-based method and cAMP was quantified by enzyme-linked immunosorbent assays to verify activation of PTGER2 and PTGFR by their corresponding agonists in these cells. OVGP1 mRNA and protein expression was measured using RT-qPCR and western blotting, respectively, following PTGER2 and PTGFR agonist-induced activation. PTGER1, PTGER2, PTGER4, and PTGFR were found to be present in BOECs; however, PTGER3 expression was not detected. OVGP1 expression was significantly promoted by $10^{-6} \mathrm{M}$ butaprost (a PTGER2 agonist) and decreased by $10^{-6} \mathrm{M}$ fluprostenol (a PTGFR agonist). In addition, $3 \mu \mathrm{M}$ H-89 (a PKA inhibitor) and $3 \mu \mathrm{M}$ U0126 (an ERK inhibitor) effectively inhibited PGE $_{2}$-induced upregulation of OVGP1, and $5 \mu \mathrm{M}$ chelerythrine chloride (a PKC inhibitor) and $3 \mu \mathrm{M} \mathrm{U} 0126$ negated OVGP1 downregulation by PGF $2 \alpha$. In conclusion, this study demonstrates that OVGP1 expression in BOECs is enhanced by $\mathrm{PGE}_{2}$ via PTGER2-cAMP-PKA signaling, and reduced by $\mathrm{PGF}_{2 \alpha}$ through the PTGFR-Ca ${ }^{2+}-\mathrm{PKC}$ pathway.
\end{abstract}

Key words: Oviduct, Oviductal glycoprotein $1(\mathrm{OVGP} 1)$, Prostaglandin $\mathrm{E}_{2}\left(\mathrm{PGE}_{2}\right)$, Prostaglandin $\mathrm{F}_{2 \alpha}\left(\mathrm{PGF}_{2 \alpha}\right)$, PTGER2, PTGFR

$\mathbf{P}$ rostaglandins (PGs), a family of bioactive lipids including $\mathrm{PGE}_{2}, \mathrm{PGF}_{2 \alpha}, \mathrm{PGD}_{2}, \mathrm{PGI}_{2}$ and thromboxane $\mathrm{A}_{2}$, are produced from arachidonic acid by cyclooxygenase-1 (COX-1), COX-2, and specific PG synthases [1-3]. PGs play important roles in many reproductive processes, such as ovulation, menstruation, fertilization, implantation, and parturition [2, 4]. Wijayagunawardane et al. have demonstrated that $\mathrm{PGE}_{2}$ and $\mathrm{PGF}_{2 \alpha}$ can be secreted by bovine oviductal epithelial cells (BOECs) [5]. PGF $_{2 \alpha}$ is involved in uterine smooth muscle contraction [6] and contributes to the retention of sperm at the junction of the uterus and oviduct, whereas $\mathrm{PGE}_{2}$ interacts with the hypothalamus and causes the secretion of luteinizing hormone [7]. In early childbirth, the level of $\mathrm{PGF}_{2 \alpha}$ in the amniotic fluid increases significantly [8], and $\mathrm{PGF}_{2 \alpha}$ receptor (PTGFR)-knockout mice cannot initiate birth [9]. Studies have shown that binding of $\mathrm{PGF}_{2 \alpha}, \mathrm{PGI}_{2}$, and $\mathrm{PGE}_{2}$ to their receptors is important in the regulation of smooth

Received: July 7, 2017

Accepted: November 28, 2017

Published online in J-STAGE: December 23, 2017

(C)2018 by the Society for Reproduction and Development

Correspondence: J Cao (e- mail: jinshancao@imau.edu.cn)

*These authors contributed equally to this work.

This is an open-access article distributed under the terms of the Creative Commons Attribution Non-Commercial No Derivatives (by-nc-nd) License. (CC-BY-NC-ND 4.0: https://creativecommons.org/licenses/by-nc-nd/4.0/) muscle contraction and secretion active substance in human oviducts [10]. In addition, such binding has significant functions in gamete transmission, fertilization, and early embryo development through suitable constriction in the oviduct [11]. Together, PGs are among the most important regulatory factors underlying the activities of the oviduct.

As a reproductive organ, the oviduct is key in the regulation of mammalian reproduction, creating a microenvironment facilitating gamete and early embryo development [12]. A family of molecules known as oviductins, including oviductal glycoprotein 1 (OVGP1), are among the various factors secreted by oviductal epithelial cells [13]. These molecules contribute to maintaining the viability and motility of bovine sperm, and possibly modulate their capacitation [14]. It is unknown whether there exists an association between PGs and OVGP1 secretion by oviductal epithelial cells. Therefore, in this study, the expression of receptors of $\mathrm{PGE}_{2}$ (PTGERs) and $\mathrm{PGF}_{2 \alpha}$ in BOECs was measured, and the effects of PTGER2 and PTGFR activation on OVGP1 expression in these cells were investigated in vitro.

\section{Materials and Methods}

Ethics statement

All of the animal studies in the present work were conducted in 
Table 1 Primers used in this study

\begin{tabular}{|c|c|c|c|}
\hline Genes & Nucleotide sequence ( $\left.5^{\prime}-3^{\prime}\right)$ & Length (bp) & GenBank accession number \\
\hline \multirow[t]{2}{*}{$\beta$-actin } & Forward 5'CCAAGGCCAACCGTGAGAAGAT3' & 256 & NM_173979.3 \\
\hline & Reverse 5'CCACGTTCCGTGAGGATCTTCA3’ & & \\
\hline \multirow[t]{2}{*}{ OVGP1 } & Forward 5' CACCTCCTCAAAGCCTCACAGA 3' & 194 & NM_001080216.1 \\
\hline & Reverse 5' TCATAGCCAACCCACTCCTTCC 3' & & \\
\hline \multirow[t]{2}{*}{ PTGERI } & Forward 5' TGGTGGTGGTGCTGGCTGTC3' & 221 & NM_001192148 \\
\hline & Reverse 5'GCTGGCCTCCCAAGGTGCTCTTGGTTT3' & & \\
\hline \multirow[t]{2}{*}{ PTGER2 } & Forward 5'GGAGCGCTACCTAGCCATC3' & 229 & AF539402.1 \\
\hline & Reverse 5'GATGAGCAACAGCAGCAGAG3' & & \\
\hline \multirow[t]{2}{*}{ PTGER3 } & Forward 5' CAGTATGGCAAAGGCAGAA3' & 288 & NM_181032.1 \\
\hline & Reverse 5'CCGCACTGGTACTCAAGC3' & & \\
\hline \multirow[t]{2}{*}{ PTGER4 } & Forward 5'CGGTGATGTTCATCTTCGG3' & 302 & NM_174589.2 \\
\hline & Reverse 5'GTAGGCGTGGTTGATGGC3' & & \\
\hline \multirow[t]{2}{*}{ PTGFR } & Forward 5'GCAGACCAAGCACAGTGAAA3' & 151 & NM_181025.3 \\
\hline & Reverse 5'CTGACAGCCAACCACGTATG3' & & \\
\hline
\end{tabular}

accordance with the experimental practices and standards approved by the Animal Welfare and Research Ethics Committee of Inner Mongolia Agricultural University (Approval ID: 2011-1).

\section{Cell culture and treatments}

Fresh oviducts were provided by a local abattoir on the day of slaughter, being transported to the laboratory in ice-cold physiological saline within $4 \mathrm{~h}$. The cows were judged to be in proestrus based on previous evidence that $\mathrm{PGE}_{2}$ and $\mathrm{PGF}_{2 \alpha}$ secretion levels are lower during this stage than other stages of the estrous cycle [15]. The ampullae of the oviducts were cut open longitudinally and washed once with sterile PBS, before being washed three times with PBS containing penicillin-streptomycin $(100 \mathrm{IU} / \mathrm{ml})$. The lumens of 10 oviducts were then gently scraped. In a previous study, we found that the smooth muscle of the ampulla, rather than the isthmus, exhibits stronger contraction and PG secretion [16]. The harvested cells were washed three times with PBS and trypsinized for $3 \mathrm{~min}$, which was terminated with phenol red-free Dulbecco's modified Eagle's medium (DMEM) (Gibco BRL, Gaithersburg, MD) containing 15\% fetal calf serum (FCS). Cells were seeded at $1 \times 10^{5} \mathrm{ml}^{-1}$ in DMEM containing $15 \%$ FCS. Once an $85 \%$ confluent monolayer had formed, the cells were trypsinized and re-plated. To eliminate any effects of endogenous PGs and other hormones, fourth-generation cells were used in the experiments. Cell viability was determined by trypan blue exclusion, and the proportion of viable BOECs in cultures used for experiments was always greater than $90 \%$. Cell type was verified using the epithelial cell-specific marker cytokeratin, for which $90 \%$ of the cultured cells were positive.

Fourth-generation BOECs were plated in dishes [12-well dishes for mRNA extraction and enzyme-linked immunosorbent assays (ELISAs), 96-well dishes for $\mathrm{Ca}^{2+}$ measurement, and 6-well dishes for protein assays]. When the cell monolayer reached approximately $90 \%$ confluency, the culture supernatant was replaced with serum- and phenol red-free medium. After incubating the cells for $12 \mathrm{~h}$, control BOECs were cultured in parallel. Then, after 2, 4, 8, 16, 24, and $48 \mathrm{~h}$, the cultures were tested for OVGP1 expression. Butaprost (a
PTGER2 agonist, $10^{-6} \mathrm{M}$ ) (Cayman Chemical, Ann Arbor, MI) and fluprostenol (a PTGFR agonist, $10^{-6} \mathrm{M}$ ) (Cayman) were added to the experimental BOECs cultures, and the experimental and control BOECs were cultured in separate dishes in parallel. Expression of OVGP1 was subsequently measured after $2,4,8,16,24$, and $48 \mathrm{~h}$ and compared to that of the cells cultured in the absence of receptor agonists. H-89 (a PKA inhibitor, $3 \mu \mathrm{M}$ ) (Sigma-Aldrich, St. Louis, $\mathrm{MO}$ ), chelerythrine chloride (a PKC inhibitor, $5 \mu \mathrm{M}$ ) (Sigma-Aldrich), and U0126 (an ERK inhibitor, $3 \mu \mathrm{M}$ ) (Sigma-Aldrich) were added to the experimental BOECs cultures, and the experimental and control BOECs were then cultured in separate dishes in parallel. OVGP1 expression was determined after $4 \mathrm{~h}$ and compared with that of cells cultured in the absence of inhibitors.

\section{RNA extraction, reverse transcription, and $q P C R$}

Total RNA was extracted from cells using RNAiso Plus (Takara, Kusatsu, Japan) according to the manufacturer's instructions at 2, $4,8,16,24$, and $48 \mathrm{~h}$ post-stimulation, and treated with DNase I to prevent DNA contamination. cDNA was then prepared using a PrimeScript ${ }^{\mathrm{TM}}$ RT Reagent Kit (Takara). qPCR was performed using SYBR Premix Ex Taq ${ }^{\mathrm{TM}}$ II (Takara), $500 \mathrm{ng}$ cDNA, and $400 \mathrm{nM}$ primers. The composition of the qPCR mixture was based on the SYBR Premix Ex Taq ${ }^{\mathrm{TM}}$ II manufacturer's instructions, and was as follows: $12.5 \mu \mathrm{l}$ SYBR Premix Ex Taq ${ }^{\mathrm{TM}}$ II, $1 \mu$ l forward primer, 1

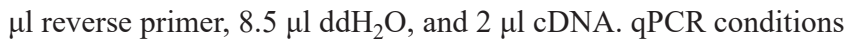
consisted of an initial denaturation at $95^{\circ} \mathrm{C}$ for $30 \mathrm{sec}$, followed by 40 amplification cycles $\left(95^{\circ} \mathrm{C}\right.$ for $5 \mathrm{sec}$ and $60^{\circ} \mathrm{C}$ for $\left.34 \mathrm{sec}\right)(\mathrm{n}=6)$. cDNA levels were determined with the $2^{-\Delta \mathrm{Ct}}$ method, using $\beta$-actin as an internal control. Sequences of the primers employed in these assays, which were designed with Primer5.0 software (Premier company, Canada), are listed in Table 1.

\section{Western blotting}

Proteins were extracted from fourth-generation cells for western blotting. In brief, cells were washed in physiological salt, treated with $300 \mu \mathrm{l}$ cell lysis buffer containing $1 \%$ proteinase inhibitors, and 


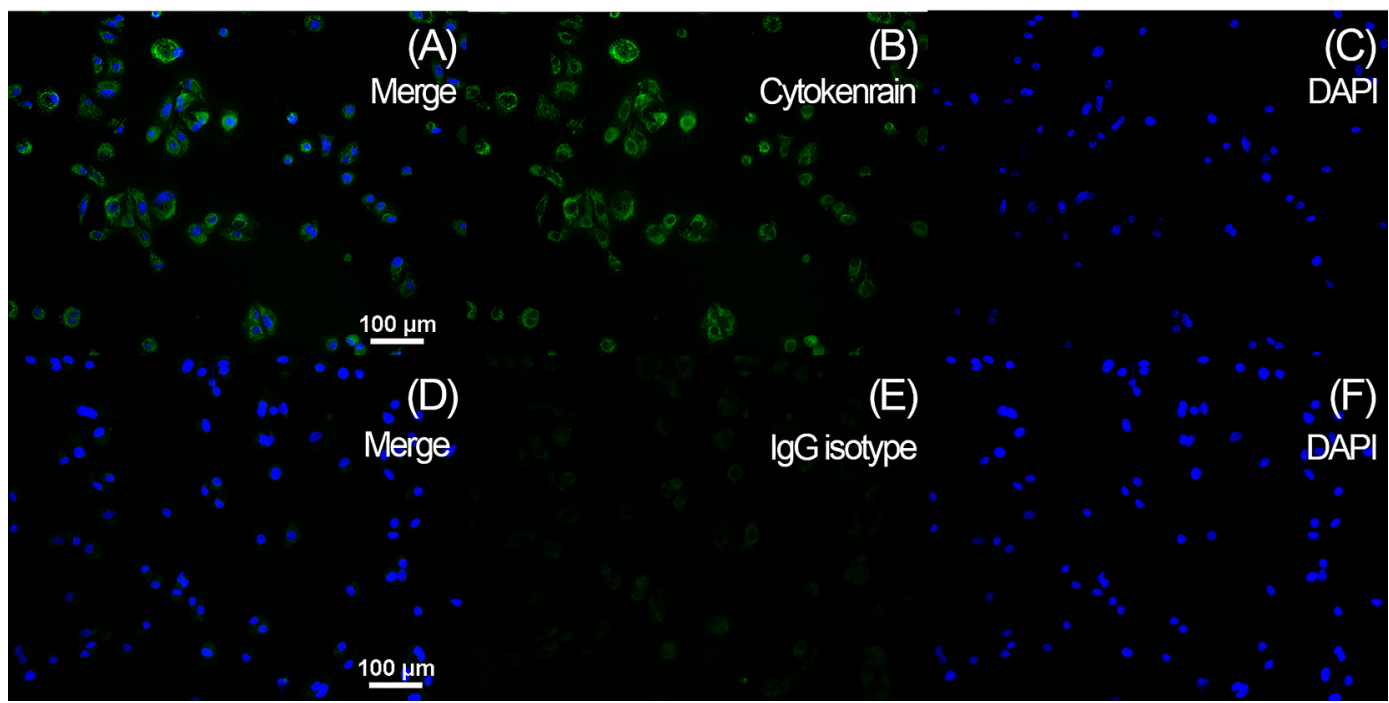

Fig. 1. Identification of cultured bovine oviductal epithelial cells (BOECs) by fluorescence microscopy. Upper panels: (A) merge of cytokeratin (green) and nuclear (blue) staining; (B) cytokeratin (epithelial cell marker, green) staining in BOECs; (C) nuclear staining (DAPI, blue). Lower panels: (D) Merge of IgG isotype control and nuclear staining; (E) IgG isotype control staining; (F) nuclear staining (DAPI, blue).

centrifuged at $14,000 \mathrm{~g}$ for $10 \mathrm{~min}$ at $4^{\circ} \mathrm{C}$ to obtain the supernatant. Protein concentration was measured with the bicinchoninic acid (BCA) method. The samples (containing $80-100 \mu$ grotein) $(n=4)$ were mixed with sample buffer (5\% SDS, 5\% dithiothreitol, $50 \mathrm{mM}$ Tris-HCl, and 50\% glycerol; $\mathrm{pH} 6.8$ ) at a ratio of 1:5, and heated at $100^{\circ} \mathrm{C}$ for $5 \mathrm{~min}$ before being subjected to SDS-PAGE on $10 \%$ gels for $2 \mathrm{~h}$ at $120 \mathrm{~V}$. The proteins in the gels were electroblotted onto PVDF membranes for $90 \mathrm{~min}$ at $350 \mathrm{~mA}$. After blocking for $2 \mathrm{~h}$, the membranes were incubated overnight at $4^{\circ} \mathrm{C}$ with polyclonal primary antibodies against OVGP1 (diluted 1:200; sc-46432; Santa Cruz Biotechnology, Dallas, TX) and $\beta$-actin (diluted 1:1,000; ab16039; Abcam, Cambridge, UK). Horseradish peroxidase (HRP)-conjugated donkey anti-goat (Santa Cruz Biotechnology) and HRP-conjugated goat anti-mouse secondary antibodies (Cell Signaling Technology, MA) diluted 1:3,000 and SuperSignal West Femto (Thermo Scientific, Waltham, MA) chemiluminescent substrate were used to detect bound primary antibodies. High-performance chemiluminescence film was subsequently exposed to the membranes, and protein band densities were analyzed using ImageJ software (please see https:// imagej.net/Citing).

\section{Immunofluorescence}

Fourth-generation BOECs were seeded in 6-well slides. When the cell monolayers reached approximately $90 \%$ confluency, they were fixed with cold acetone for $15 \mathrm{~min}$ and washed with PBS. The cells were subsequently blocked with $10 \%$ goat serum and incubated with a primary antibody against cytokeratin (ab668; Abcam) at $4{ }^{\circ} \mathrm{C}$ overnight, followed by an Alexa Fluor ${ }^{\circledR}$ 488-conjugated goat antimouse secondary antibody (Abcam) for $2 \mathrm{~h}$. A mouse IgG isotype control (R\&D Systems, Minneapolis, MN) was used in this study.
Effects of $P G E_{2}$ and $P G F_{2 \alpha}$ on $\mathrm{Ca}^{2+}$ concentration

$\mathrm{Ca}^{2+}$ concentration was measured after butaprost and fluprostenol treatment of fourth-generation BOECs. Cells were incubated with the fluorescent indicator fluo3-AM (3 $\mu$ M; s1056; Beyotime, Shanghai, China) at $37^{\circ} \mathrm{C}$ for $30 \mathrm{~min}$, and subsequently washed three times with PBS to remove any excess. Next, $100 \mu \mathrm{l}$ PBS was added, and the cells were examined using a multimode reader at $37^{\circ} \mathrm{C}$ with excitation at $\lambda=488 \mathrm{~nm}$ and emission at $\lambda=528 \mathrm{~nm}$. The following formula was then applied: $\left[\mathrm{Ca}^{2+}\right]=\mathrm{Kd}[(\mathrm{F}-\mathrm{Fmin}) /(\mathrm{Fmax}-\mathrm{F})]$, where $\mathrm{Kd}=$ $450,(\mathrm{Kd}$ means the dissociation constant and $\mathrm{F}$ means fluorescence).

Effects of $P G E_{2}$ and $P G F_{2 \alpha}$ on $C A M P$ concentration in BOECs

Fourth-generation BOECs were incubated at $37^{\circ} \mathrm{C}$ for $1 \mathrm{~h}$ with medium containing $10^{-3} \mathrm{M}$ IBMX(3-Isobutyl-1-methyxanthine). Following application of $10^{-9}, 10^{-8}, 10^{-7}, 10^{-6}$, or $10^{-5} \mathrm{M} \mathrm{PGE}_{2}$ or butaprost for $5 \mathrm{~min}$ (with the exception of the control BOECs, to which no drugs or medium were added), liquid nitrogen was used to terminate the reaction, and the solution was removed by washing three times with PBS. The cells were then exposed to $1 \mathrm{ml} 1 \mathrm{M} \mathrm{HCl}$ for $20 \mathrm{~min}$, before being transferred to a centrifuge tube and centrifuged at $1,200 \mathrm{~g}$ for $10 \mathrm{~min}$ to obtain the supernatant. cAMP concentration was measured with a cAMP EIA Kit (581001; Cayman Chemical). The concentration of protein in each sample was measured using the BCA method and used as an internal reference.

\section{Statistical analysis}

All data are presented as means \pm standard errors of the mean. Statistical significance was analyzed using one-way analysis of variance followed by post hoc analysis (Dunnett's test for the data in Fig. 2B, C, and D and Fig. 3A, B, C, and D; Tukey's test for those in Fig. 3E and F and Fig. 4). P-values less than 0.05 were considered to indicate significant differences. GraphPad Prism 5 
A

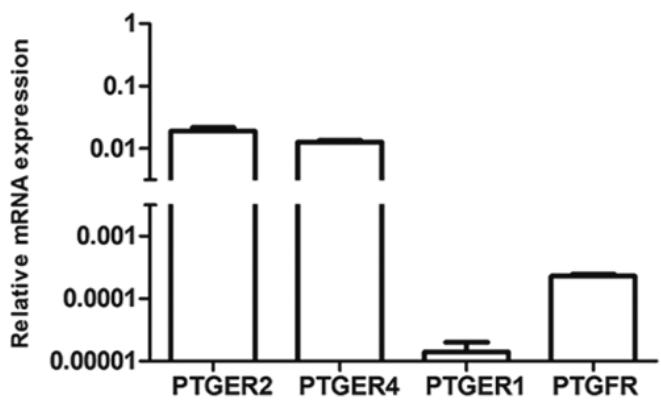

C

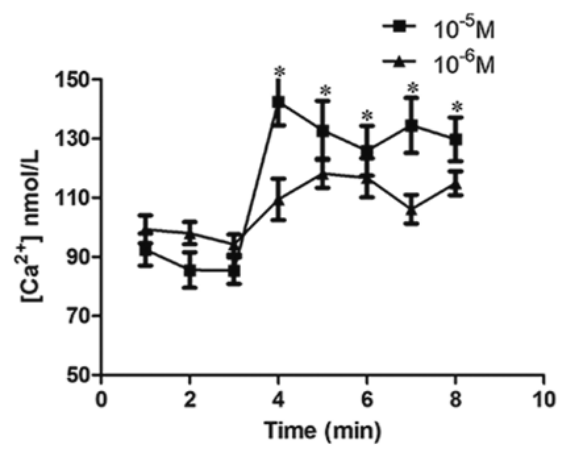

B

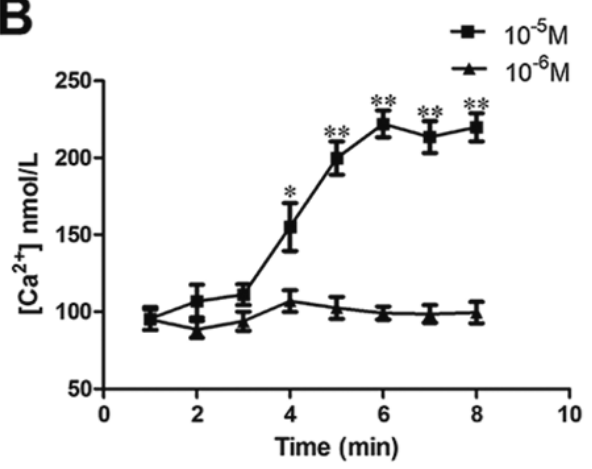

D

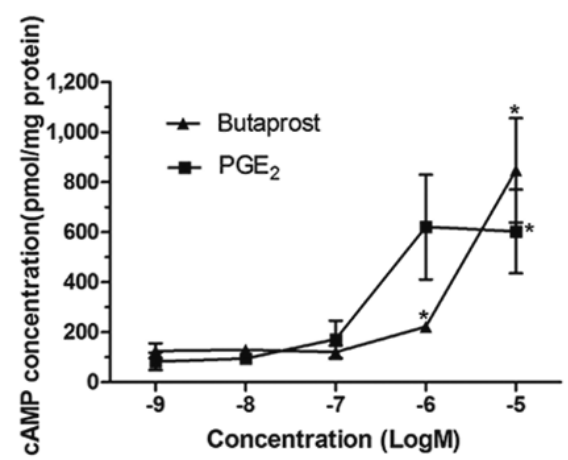

Fig. 2. Expression of prostaglandin (PG) receptors in bovine oviductal epithelial cells (BOECs) was measured using RT-qPCR (A). Effects of PGE 2 (B) and $\mathrm{PGF}_{2 \alpha}(\mathrm{C})$ on $\left[\mathrm{Ca}^{2+}\right]$ in BOECs. Effects of $\mathrm{PGE}_{2}$ and butaprost on cAMP levels in BOECs (D). Data are means \pm standard errors of the mean from four independent experiments; ${ }^{*} \mathrm{P}<0.05, * * \mathrm{P}<0.01$.

software (GraphPad Software, La Jolla, CA) was used to conduct the statistical analysis.

\section{Results}

\section{Cultured BOEC morphology}

As shown in Fig. 1, BOECs were found to be polygonal or irregularly shaped, with clear borders and closely packed, granular cytoplasm. Their nuclei were large and circular.

\section{Expression of receptors of $P G E_{2}$ and $P G F_{2 \alpha}$ in BOECs}

PTGER1, PTGER2, PTGER4, and PTGFR were found to be present in BOECs (Fig. 2A); however, PTGER3 expression was not detected (not shown). Whereas $10^{-5} \mathrm{M} \mathrm{PGE}_{2}$ significantly increased $\mathrm{Ca}^{2+}$ concentration in these cells $(\mathrm{P}<0.01), 10^{-6} \mathrm{M} \mathrm{PGE}_{2}$ had little to no effect in this regard (Fig. 2B). Furthermore, $10^{-6} \mathrm{M}$ and $10^{-5}$ $M \mathrm{PGF}_{2 \alpha}$ significantly raised the concentration of $\mathrm{Ca}^{2+}$ in BOECs $(\mathrm{P}<0.05)$ (Fig. 2C), suggesting the existence of Gq protein-coupled receptors in these cells, and implying that $\mathrm{PGE}_{2}$ and $\mathrm{PGF}_{2 \alpha}$ increased $\mathrm{Ca}^{2+}$ concentration through activation of their corresponding receptors. The concentration of cAMP in BOECs significantly increased as the concentration of $\mathrm{PGE}_{2}$ was raised. Administration of $10^{-5}$ and $10^{-6}$ $\mathrm{M} \mathrm{PGE} 2$ or $10^{-5} \mathrm{M}$ butaprost resulted in significantly heightened
BOEC cAMP concentration (Fig. 2D).

PTGER2 and PTGFR mediate OVGP1 expression in BOECs

To determine whether the receptors PTGER2 and PTGFR mediate regulation of OVGP1 expression in BOECs, we treated these cells with selective receptor agonists and antagonists to evaluate their effects on OVGP1 mRNA and protein expression. No significant difference $(\mathrm{P}<0.05)$ in the expression of OVGP1 was noted between the treatment groups at $0 \mathrm{~h}$ and the control group at any time point (data not shown). Therefore, the $0 \mathrm{~h}$ time point was used as the control. Expression of OVGP1 mRNA and protein was significantly increased $4 \mathrm{~h}$ and $8 \mathrm{~h}$ following treatment with $10^{-6} \mathrm{M}$ butaprost (a PTGER2 agonist) compared with the control (Fig. $3 \mathrm{~A}$ and $3 \mathrm{~B}$ ). In addition, $10^{-5}$ M AH6809 (a PTGER2 antagonist) significantly inhibited the upregulation of OVGP1 mRNA and protein induced by treatment with butaprost for $4 \mathrm{~h}$ (Fig. $3 \mathrm{E}$ and $3 \mathrm{~F}$ ). These results suggest that $\mathrm{PGE}_{2}$ promotes OVGP1 expression through activation of PTGER2 in BOECs. In contrast, addition of $10^{-6} \mathrm{M}$ fluprostenol (a PTGFR agonist) led to significant suppression of OVGP1 mRNA and protein expression at all tested time points, most notably so at $2 \mathrm{~h}$ and 4 $\mathrm{h}(\mathrm{P}<0.01$, Fig. 3C and 3D). Moreover, this fluprostenol-induced downregulation of OVGP1 mRNA and protein was blocked to a significant extent by $10^{-5} \mathrm{M}$ AL8810 (a PTGFR antagonist; Fig. 3E 

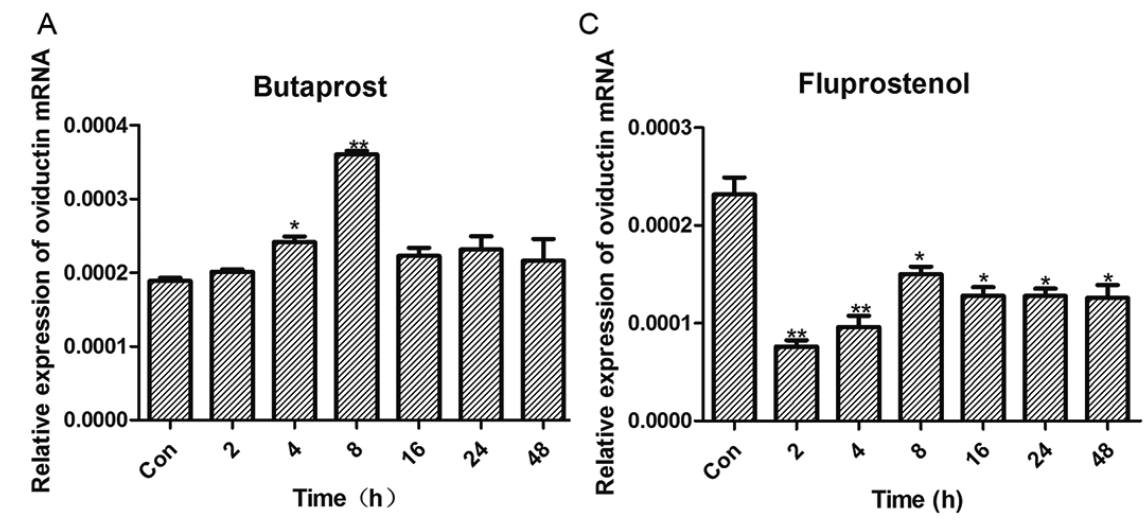

E

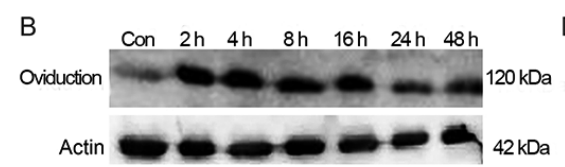

D
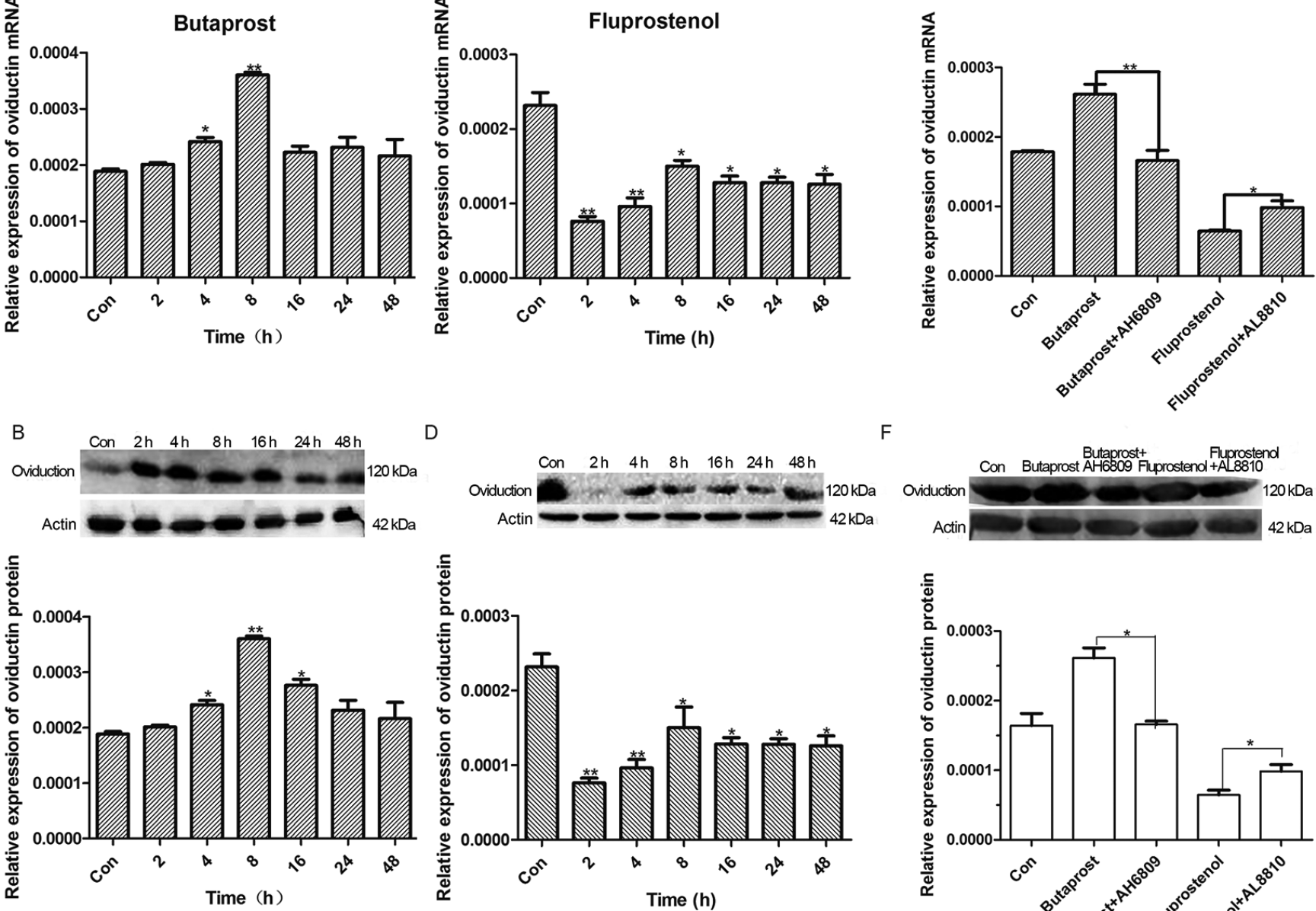

$\mathrm{F}$
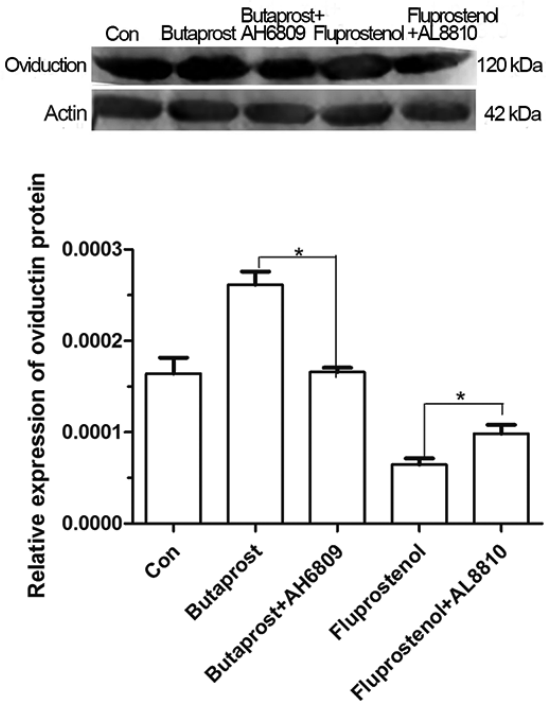

Fig. 3. PTGER2 and PTGFR mediate OVGP1 expression in bovine oviductal epithelial cells. Effects of $10^{-6} \mathrm{M}$ butaprost on OVGP1 mRNA (A) and protein expression (B). Effects of $10^{-6} \mathrm{M}$ fluprostenol on OVGP1 mRNA (C) and protein expression (D). Effects of AH6809 and AL8810 (both $10^{-6} \mathrm{M}$ ) on OVGP1 mRNA (E) and protein expression $(\mathrm{F})$. Data are means \pm standard errors of the mean from four independent experiments; * $\mathrm{P}$ $<0.05$, ** $\mathrm{P}<0.01$. Con, control.

and $3 \mathrm{~F}$ ). These results suggest that the interaction between $\mathrm{PGF}_{2 \alpha}$ and PTGFR results in inhibition of OVGP1 expression.

\section{Effects of PKA, PKC, and ERK inhibitors on PGE $2^{-}$and $P G F_{2 \alpha}$-mediated OVGP1 expression in BOECs}

To identify the intracellular signal transduction pathways involved in $\mathrm{PGE}_{2}$ - and $\mathrm{PGF}_{2 \alpha}$-mediated OVGP1 regulation in BOECs, we examined the effects of PKA, PKC, and ERK inhibitors on $\mathrm{PGE}_{2}$ - and $\mathrm{PGF}_{2 \alpha}$-induced OVGP1 expression. $\mathrm{PGE}_{2}$ significantly increased OVGP1 mRNA (4 h) and protein $(8 \mathrm{~h})$ expression in BOECs, and addition of $3 \mu \mathrm{M} \mathrm{H}-89$ (a PKA inhibitor) or $3 \mu \mathrm{M}$ U0126 (an ERK inhibitor) markedly inhibited this effect (Fig. 4A and 4B). These results suggest that OVGP1 expression was promoted by $\mathrm{PGE}_{2}$ via the PTGER2-cAMP-PKA-ERK pathway. In contrast, $\mathrm{PGF}_{2 \alpha}$ significantly decreased expression of OVGP1 mRNA $(4 \mathrm{~h})$ and protein $(8 \mathrm{~h})$ in BOECs, similar to the effects of fluprostenol, and addition of $5 \mu \mathrm{M}$ chelerythrine chloride (a PKC inhibitor) or $3 \mu \mathrm{M}$ U0126 effectively blocked this $\mathrm{PGF}_{2 \alpha}$-induced suppression of OVGP1 expression (Fig. 4C and 4D). This indicates that expression of OVGP1 was restricted by $\mathrm{PGF}_{2 \alpha}$ through the PTGFR-Ca ${ }^{2+}-\mathrm{PKC}-\mathrm{ERK}$ pathway.

\section{Discussion}

In the present study, we evaluated the effects of the PTGER2 agonist butaprost and the PTGFR agonist fluprostenol on OVGP1 mRNA and protein levels in BOECs using RT-qPCR and western blotting, respectively. Our results showed that butaprost and fluprostenol significantly promoted and suppressed OVGP1 expression in BOECs, respectively. Moreover, $\mathrm{PGE}_{2}$ was shown to promote expression of OVGP1 through its receptor PTGER2, and $\mathrm{PGF}_{2 \alpha}$ to exert a down regulatory effect on OVGP1 via activation of its receptor PTGFR. Furthermore, the possibility that $\mathrm{PGE}_{2}$ and $\mathrm{PGF}_{2 \alpha}$ affect OVGP1 

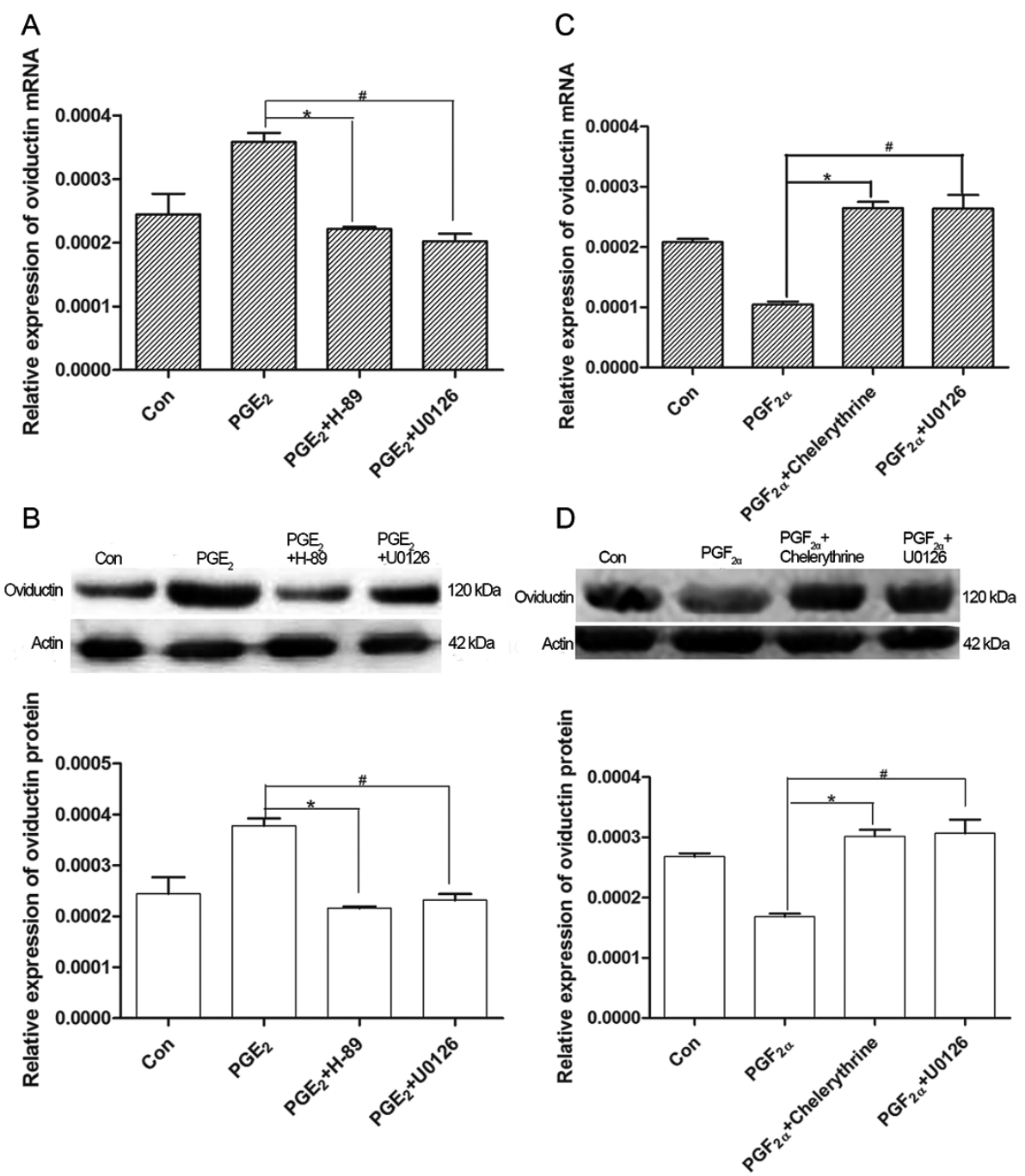

Fig. 4. Effects of PKA, PKC, and ERK inhibitors on $\mathrm{PGE}_{2}$ - and $\mathrm{PGF}_{2 \alpha}$-mediated changes in OVGP1 expression in bovine oviductal epithelial cells. Effect of PKA and ERK inhibitors on OVGP1 mRNA (A) and protein expression (B). Effect of PKC and ERK inhibitors on OVGP1 mRNA (C) and protein expression (D); * and ${ }^{\#} \mathrm{P}<0.05$. Con, control.

through the PTGER2-cAMP-PKA and PTGFR-Ca ${ }^{2+}$-PKC signaling pathways, respectively, has been strengthened by our data.

OVGP1 is the primary component of oviduct secretions. Mugnier et al. have demonstrated that oviductal epithelial cell secretions can increase the rate of in vitro fertilization in horses, and have speculated that OVGP1 is involved in the fertilization process [17]. This conclusion has also been reached by Goncalves et al. [18], who indicated that OVGP1 also plays an important role in fertilization in the cow oviduct. Transferal of sperm to the oviduct stimulates oviductal epithelial cells to secrete high levels of PGs, which may target either sperm or oviductal epithelial cells themselves [19, 20]. However, no reports indicating the expression of receptors of $\mathrm{PGE}_{2}$ and $\mathrm{PGF}_{2 \alpha}$ on sperm cells have been published to our knowledge, suggesting that $\mathrm{PGE}_{2}$ and $\mathrm{PGF}_{2 \alpha}$ secreted by oviductal epithelial cells act on these cells themselves, or on targets such as oviductal stromal cells and fertilized eggs. Oviductal epithelial cells play important roles in reproduction, including in fertilization and early embryonic development. They also serve as a model for studies of the oviduct and related areas of research [21]. In the current work, we cultured BOECs in vitro (Fig. 1) and used them to analyze the effect of receptors of $\mathrm{PGE}_{2}$ and $\mathrm{PGF}_{2 \alpha}$ on OVGP1 expression.

$\mathrm{PGE}_{2}$ and $\mathrm{PGF}_{2 \alpha}$ are found in semen, cervical fluid, and the oviduct. $\mathrm{PGE}_{2}$ receptors are divided into four subtypes: PTGER1, PTGER2, PTGER3, and PTGER4, whereas only one $\mathrm{PGF}_{2 \alpha}$ receptor has been identified (PTGFR) [22]. Our results indicated that PTGER1, PTGER2, PTGER4, and PTGFR were present in BOECs. Furthermore, PTGER2 and PTGER4 were highly expressed in these cells, whereas PTGER1 and PTGFR expression was low. As mentioned above, $\mathrm{PGF}_{2 \alpha}, \mathrm{PGE}_{2}$, and butaprost significantly increased intracellular $\mathrm{Ca}^{2+}$ and cAMP levels (Fig. 2), suggesting that PTGER2 and PTGFR are functional in BOECs. Although PTGER1 and PTGER4 are expressed in oviductal epithelial cells, knockout studies in mice have shown that 
PTGER2, rather than PTGER1, PTGER3, or PTGER4, is associated with reproductive dysfunction [23]. Therefore, in the present work, we primarily focused on the effect of $\mathrm{PGE}_{2}$ and activation of its receptor PTGER2 on OVGP1 expression in oviductal epithelial cells. In order to clarify the nature of OVGP1 regulation by $\mathrm{PGE}_{2}$ and $\mathrm{PGF}_{2 \alpha}$, we determined the effects of PTGER2 and PTGFR on OVGP1 synthesis in BOECs.

$\mathrm{PGE}_{2}$ is the main hormone regulating early and late egg growth in the uterus [24]. Throughout gestation, regulation by $\mathrm{PGE}_{2}$ predominates, influencing the effects of OVGP1. OVGP1 expression increases during the estrus cycle, but this increase is transient and $\mathrm{PGF}_{2 \alpha}$ is required to adjust the balance. $\mathrm{PGE}_{2}$ possesses luteoprotective properties, whereas $\mathrm{PGF}_{2 \alpha}$ is a luteolysin in ruminants $[25,26]$. Other similar studies have suggested that $24 \mathrm{~h}$ after the effects of estrogen are observed, maintenance of $\mathrm{PGE}_{2}$ levels and a decrease in $\mathrm{PGF}_{2 \alpha}$ concentration lead to an increased $\mathrm{PGE}_{2} / \mathrm{PGF}_{2 \alpha}$ ratio [27]. Kaczmarek et al. reported that seminal plasma affects $\mathrm{PGE}_{2}$ and $\mathrm{PGF}_{2 \alpha}$ synthesis in the porcine oviduct to increase this ratio [20]. $\mathrm{PGE}_{2}$ and $\mathrm{PGF}_{2 \alpha}$ have opposing effects, but it has been suggested that their expression is coordinated to achieve a balance in vivo. It has also been proposed that PGF $2 \alpha$ significantly stimulated intraluteal $\mathrm{PGF}_{2 \alpha}$ production in all luteal phases, but did not affect PGE2 production [28]. $\mathrm{PGE}_{2}$ rapidly increased TbetaRIII mRNA and protein expression and enhanced TbetaRIII gene promoter activity ctivity, whereas $\mathrm{PGF}_{2 \alpha}$ does not [29]. De Moraes et al. reported that PTGFR mRNA expression is stable during pregnancy in cows, and lower in rats postpartum [30]. The results of the present study indicate that in BOECs, $\mathrm{PGE}_{2}$ promotes OVGP1 expression via activation of PTGER2, and $\mathrm{PGF}_{2 \alpha}$ downregulates OVGP1 via PTGFR activation. The different regulatory effects of PGs on OVGP1 expression might contribute to the maintenance of a balanced state within the oviduct.

The inducible COX-2 enzyme modulates PGE $_{2}$-PTGER2-cAMPPKA singling [31]. In addition, $\mathrm{PGE}_{2}$ has been reported to induce VEGF expression through activation of the $\mathrm{PGE}_{2}$-Gas-cAMP-PKA signaling pathway [32]. Via PTGFR, $\mathrm{PGF}_{2 \alpha}$ upregulates COX-2 expression through PKC activation in human amniotic fibroblasts [33] and activates the PLC system during the mid-luteal phase [34]. The simultaneous activation of PTGER2 and PTGFR amplifies cAMP release through the PTGFR- Gq protein- $\mathrm{Ca}^{2+}$ signaling pathway [32]. Therefore, we speculate that $\mathrm{PGE}_{2}$ promotes OVGP1 expression via PTGER2 activation and the cAMP-PKA signaling pathway, while $\mathrm{PGF}_{2 \alpha}$ downregulates OVGP1 via PTGFR activation and $\mathrm{Ca}^{2+}$-PKC signaling. Our results showed that $\mathrm{PGE}_{2}$-induced OVGP1 expression was significantly suppressed by H-89 and U0126 treatment, suggesting that OVGP1 in BOECs is regulated through the $\mathrm{PGE}_{2}$-PTGER2-cAMP-PKA pathway and resulting activation of ERK signaling. Moreover, reduction of OVGP1 expression by $\mathrm{PGF}_{2 \alpha}$ in BOECs was found to be negated by administration of chelerythrine chloride and U0126, indicating that the $\mathrm{PGF}_{2 \alpha}-\mathrm{PTGFR}-\mathrm{Ca}^{2+}-\mathrm{PKC}$ pathway and simultaneous regulation of ERK activation are also involved in OVGP1 regulation in these cells. Together, these findings contribute to clarifying the molecular mechanisms underlying the effect of $\mathrm{PGE}_{2}$ and $\mathrm{PGF}_{2 \alpha}$ on OVGP1 synthesis.

In conclusion, this study supports the idea that in BOECs, $\mathrm{PGE}_{2}$ promotes OVGP1 expression via activation of PTGER2, whereas $\mathrm{PGF}_{2 \alpha}$ downregulates OVGP1 by activating PTGFR. In these cells, the upregulatory effect of $\mathrm{PGE}_{2}$ on OVGP1 is exerted via PTGER2cAMP-PKA signaling, and is counterbalanced by $\mathrm{PGF}_{2 \alpha}$ through the PTGFR-Ca ${ }^{2+}$-PKC pathway. These results represent an essential next step in understanding the regulatory effects of these PGs on the mammalian oviduct and changes in the biological components of oviduct fluid.

Conflict of Interest: There is no conflict of interest that could be perceived as prejudicing the impartiality of the research reported.

\section{Acknowledgements}

This work was supported by grants from the National Natural Science Foundation of China (no. 3160490), the New Century Excellent Researcher Award Program of the Ministry of Education of China (no. NCET-11-1019), the Natural Science Foundation of Inner Mongolia, China (no. 2014BS0323), and the Excellent Young Scientist Foundation of Inner Mongolia Agricultural University of China (no. 2014XYQ-3).

\section{References}

1. Cao J, Wakatsuki A, Yoshida M, Kitazawa T, Taneike T. Thromboxane A2 (TP) receptor in the non-pregnant porcine myometrium and its role in regulation of spontaneous contractile activity. Eur J Pharmacol 2004; 485: 317-327. [Medline] [CrossRef]

2. Cao J, Nakamura T, Kitazawa T, Yamashiki N, Yamamoto T, Taneike T. Characterization of prostanoid receptors present on adrenergic neurons innervating the porcine uterine longitudinal muscle. Prostaglandins Other Lipid Mediat 2008; 86: 26-34. [Medline] [CrossRef]

3. Moreira V, Gutiérrez JM, Amaral RB, Lomonte B, Purgatto E, Teixeira C. A phospholipase $\mathrm{A}_{2}$ from Bothrops asper snake venom activates neutrophils in culture: expression of cyclooxygenase-2 and $\mathrm{PGE}_{2}$ biosynthesis. Toxicon 2011; 57: 288-296. [Medline] [CrossRef]

4. Salleh N. Diverse roles of prostaglandins in blastocyst implantation. Sci Word J 2014; 2014. http://dx.doi.org/10.1155/2014/968141.[CrossRef]

5. Wijayagunawardane MP, Choi YH, Miyamoto A, Kamishita H, Fujimoto S, Takagi M, Sato K. Effect of ovarian steroids and oxytocin on the production of prostaglandin E2, prostaglandin F2alpha and endothelin-1 from cow oviductal epithelial cell monolayers in vitro. Anim Reprod Sci 1999; 56: 11-17. [Medline] [CrossRef]

6. Cao J, Yosida M, Kitazawa T, Taneike T. Uterine region-dependent differences in responsiveness to prostaglandins in the non-pregnant porcine myometrium. Prostaglandins Other Lipid Mediat 2005; 75: 105-122. [Medline] [CrossRef]

7. Löffler I, Grün M, Böhmer FD, Rubio I. Role of cAMP in the promotion of colorectal cancer cell growth by prostaglandin E2. BMC Cancer 2008; 8: 380. [Medline] [CrossRef]

8. Dray F, Frydman R. Primary prostaglandins in amniotic fluid in pregnancy and spontaneous labor. Am J Obstet Gynecol 1976; 126: 13-19. [Medline] [CrossRef]

9. Sugimoto Y, Yamasaki A, Segi E, Tsuboi K, Aze Y, Nishimura T, Oida H, Yoshida N, Tanaka T, Katsuyama M, Hasumoto K, Murata T, Hirata M, Ushikubi F, Negishi M, Ichikawa A, Narumiya S. Failure of parturition in mice lacking the prostaglandin F receptor. Science 1997; 277: 681-683. [Medline] [CrossRef]

10. Huang JC, Arbab F, Tumbusch KJ, Goldsby JS, Matijevic-Aleksic N, Wu KK. Human fallopian tubes express prostacyclin (PGI) synthase and cyclooxygenases and synthesize abundant PGI. J Clin Endocrinol Metab 2002; 87: 4361-4368. [Medline] [CrossRef]

11. Dixon RE, Ramsey KH, Schripsema JH, Sanders KM, Ward SM. Time-dependent disruption of oviduct pacemaker cells by Chlamydia infection in mice. Biol Reprod 2010 83: 244-253. [Medline] [CrossRef]

12. Marey MA, Liu J, Kowsar R, Haneda S, Matsui M, Sasaki M, Takashi S, Hayakawa H, Wijayagunawardane MP, Hussein FM, Miyamoto A. Bovine oviduct epithelial cells downregulate phagocytosis of sperm by neutrophils: prostaglandin E2 as a major physiological regulator. Reproduction 2013; 147: 211-219. [Medline] [CrossRef]

13. Killian GJ. Evidence for the role of oviduct secretions in sperm function, fertilization and embryo development. Anim Reprod Sci 2004; 82-83: 141-153. [Medline] [CrossRef]

14. Sostaric E, van de Lest CH, Colenbrander B, Gadella BM. Dynamics of carbohydrate affinities at the cell surface of capacitating bovine sperm cells. Biol Reprod 2005; 72: 346-357. [Medline] [CrossRef] 
15. Tanikawa M, Acosta TJ, Fukui T, Murakami S, Korzekwa A, Skarzynski DJ, Piotrowska KK, Park CK, Okuda K. Regulation of prostaglandin synthesis by interleukin$1 \alpha$ in bovine endometrium during the estrous cycle. Prostaglandins Other Lipid Mediat 2005; 78: 279-290. [Medline] [CrossRef]

16. Su R, Wu Y, Huang N, Fu G, Cao J. Analysis of the prostaglandin receptor in the oviduct of the cow. China Animal Husbandry \& Veterinary Medicine 2010; 37: 118-123.

17. Mugnier S, Kervella M, Douet C, Canepa S, Pascal G, Deleuze S, Duchamp G, Monget P, Goudet G. The secretions of oviduct epithelial cells increase the equine in vitro fertilization rate: are osteopontin, atrial natriuretic peptide A and oviductin involved? Reprod Biol Endocrinol 2009; 7: 129. [Medline] [CrossRef]

18. Gonçalves RF, Staros AL, Killian GJ. Oviductal fluid proteins associated with the bovine zona pellucida and the effect on in vitro sperm-egg binding, fertilization and embryo development. Reprod Domest Anim 2008; 43: 720-729. [Medline] [CrossRef]

19. Roy AC, Ratnam SS. Biosynthesis of prostaglandins by human spermatozoa in vitro and their role in acrosome reaction and fertilization. Mol Reprod Dev 1992; 33: 303-306. [Medline] [CrossRef]

20. Kaczmarek MM, Krawczynski K, Blitek A, Kiewisz J, Schams D, Ziecik AJ. Seminal plasma affects prostaglandin synthesis in the porcine oviduct. Theriogenology 2010; 74: 1207-1220. [Medline] [CrossRef]

21. Abe H, Hoshi H. Bovine oviductal epithelial cells: their cell culture and applications in studies for reproductive biology. Cytotechnology 1997; 23: 171-183. [Medline] [CrossRef]

22. Hori R, Nakagawa T, Yamamoto N, Hamaguchi K, Ito J. Role of prostaglandin E receptor subtypes EP2 and EP4 in autocrine and paracrine functions of vascular endothelial growth factor in the inner ear. BMC Neurosci 2010; 11: 35. [Medline] [CrossRef]

23. Kobayashi T, Narumiya S. Function of prostanoid receptors: studies on knockout mice. Prostaglandins Other Lipid Mediat 2002; 68-69: 557-573. [Medline] [CrossRef]

24. Rogers LM, Thelen T, Fordyce K, Bourdonnay E, Lewis C, Yu H, Zhang J, Xie J, Serezani CH, Peters-Golden M, Aronoff DM. EP4 and EP2 receptor activation of protein kinase A by prostaglandin E2 impairs macrophage phagocytosis of Clostridium sordellii. Am J Reprod Immunol 2014; 71: 34-43. [Medline] [CrossRef]

25. Mlynarczuk J, Wróbel MH, Kotwica J. Adverse influence of coumestrol on secretory function of bovine luteal cells in the first trimester of pregnancy. Environ Toxicol 2013; 28: 411-418. [Medline] [CrossRef]
26. Miyamoto A, Shirasuna K, Haneda S, Shimizu T, Matsui M. CELL BIOLOGY SYMPOSIUM: perspectives: possible roles of polymorphonuclear neutrophils in angiogenesis and lymphangiogenesis in the corpus luteum during development and early pregnancy in ruminants. J Anim Sci 2014; 92: 1834-1839. [Medline] [CrossRef]

27. Dong Z, Zhang N, Mao W, Liu B, Huang N, Li P, Li C, Cao J. Kinetic effect of oestrogen on secretion of prostaglandins E2 and F2 $\alpha$ in bovine oviduct epithelial cells. Reprod Fertil Dev 2017; 29: 482-489. [Medline] [CrossRef]

28. Kumagai A, Yoshioka S, Sakumoto R, Okuda K. Auto-amplification system for prostaglandin F2 $\alpha$ in bovine corpus luteum. Mol Reprod Dev 2014; 81: 646-654. [Medline] [CrossRef]

29. McCarthy TL, Pham TH, Knoll BI, Centrella M. Prostaglandin E2 increases transforming growth factor-beta type III receptor expression through CCAAT enhancer-binding protein delta in osteoblasts. Mol Endocrinol 2007; 21: 2713-2724. [Medline] [CrossRef]

30. de Moraes CN, Maia L, de Lima PF, Dias MC, Raposo-Ferreira TM, Sudano MJ, Junior JB, Oba E. Temporal analysis of prostaglandin F2 $\alpha$ receptor, caspase 3, and cyclooxygenase 2 messenger RNA expression and prostaglandin F2 $\alpha$ receptor and cyclooxygenase 2 protein expression in endometrial tissue from multiparous Nelore (Bos taurus indicus) cows treated with cloprostenol sodium during puerperium. Theriogenology 2015 83: 276-284. [Medline] [CrossRef]

31. Steinert D, Küper C, Bartels H, Beck FX, Neuhofer W. PGE2 potentiates tonicityinduced COX-2 expression in renal medullary cells in a positive feedback loop involving EP2-cAMP-PKA signaling. Am J Physiol Cell Physiol 2009; 296: C75-C87. [Medline] [CrossRef]

32. Abera AB, Sales KJ, Catalano RD, Katz AA, Jabbour HN. EP2 receptor mediated cAMP release is augmented by PGF 2 alpha activation of the FP receptor via the calciumcalmodulin pathway. Cell Signal 2010; 22: 71-79. [Medline] [CrossRef]

33. Wang Y, Ma J, Shu W, Leng J. Prostaglandin E2 increased the expression of vascular endothelial growth factor(VEGF)by activation of cAMP-PKA pathway in hepatocellular carcinoma cells. ACTA UNIVERSITATIS MEDICINALIS NANJING 2010; 30: 299-303. (Natural Science)

34. Sen A, Choudhary E, Inskeep EK, Flores JA. Effects of selective protein kinase c isozymes in prostaglandin2alpha-induced $\mathrm{Ca}^{2+}$ signaling and luteinizing hormone-induced progesterone accumulation in the mid-phase bovine corpus luteum. Biol Reprod 2005; 72: 976-984. [Medline] [CrossRef] 